\title{
DEMOCRATIZAÇÃO PELOS "MASS MEDIA"? - O DIREITO DE SER INFORMADO E OS LIMITES FÁTICOS À SUA PLENA EFICÁCIA -
}

\author{
Airton Cerqueira Leite Seelaender \\ Aluno do 5o ano Área de Empresas da Faculdade de Direito da USP e \\ Bolsista da FAPESP, orientando do Prof. Enrique Ricardo Lewandowski
}

\begin{abstract}
Resumo: O reconhecimento, em vários ordenamentos, do direito de ser informado não tem sido acompanhado por uma correta estimativa, por parte da doutrina, dos potenciais efeitos políticos decorrentes da consagração deste instituto. Nâo têm sido levada em conta a existência de limites fáticos à plena eficácia de tal direito, tais como o crescente grau de complexidade e especialização da gestão do Estado, a impossibilidade de identificar-se a opinião pública com uma "vontade popular" concebida nos moldes da Teoria Democrática, e os contratempos a que está sujeito o processo de informação em virtude do próprio papel nele desempenhado pelos "mass media". Tais limites, embora não nos autorizem, de modo algum, a considerar o direito em tela politicamente inócuo, tornam inviável a conversão dos estados contemporâneos em ágoras eletrônicas.
\end{abstract}

\begin{abstract}
The acknowledgment, in several legal systems, of the right to be informed has not been followed by an accurate assessment, by jurists, of the potential political effects resulting from this recognition. The factual limits to the full effectiveness of this right - the increasing complexity and specialization of State managements; the impossibility of identifying public opinion with "people's will" as conceived by Democratic Theory; and the problems brought in by the participation of mass media in the information process - have not been considered so far. Although these limits do not allow us to regard the right to be informed as politically ineffectual, they prevent the transformation of contemporary states into electronic ágorai.
\end{abstract}

Unitermos: Direito de ser informado; Limites fáticos à sua eficácia; Opinião pública e vontade popular; Subgoverno tecnocrático; Limitaçôes da mídia e do público.

\section{Apresentação}

O recente reconhecimento, por vários ordenamentos jurídicos, de um direito dos governados de terem acesso às informações politicamente relevantes parece haver provocado certo desconcerto na doutrina, a qual se tem revelado incapaz de estimar corretamente o virtual impacto deste novo instituto sobre a distribuição social do poder. Com efeito, a consagração do direito de ser informado em diversas legislaçōes ensejou o surgimento simultâneo de avaliações precipitadamente céticas e comicamente otimistas do seu potencial demo- 
cratizador, já havendo mesmo quem suponha que tal direito, na era dos "mass media", possa permitir a sujeição dos vastos estados nacionais contemporâneos a uma visibilidade análoga à existente na pólis helênica.

No momento em que a análise do texto dos incisos XIV, XXXIII e LXXII do artigo 5o da nova Constituição parece dar a certos juristas brasileiros a oportunidade de se lançarem a exercícios delirantes de profecia, creio ser oportuno contribuir com alguns elementos para uma discussão mais objetiva acerca do problema da eficácia do direito de ser informado enquanto fator de democratização, apresentando aqui parte do trabalho que ultimamente tenho redigido, na condição de bolsista da Fundação de Amparo à Pesquisa do Estado de São Paulo, sob a orientação do Prof. Enrique Ricardo Lewandowski.

Em 705, Justiniano II, conhecido como "rhinotmetus" ("homem de nariz cortado") em virtude da mutilação que sofrera ao ser deposto dez anos antes, recuperou o trono bizantino, pondo fim ao hábito de se recorrer à decepação de narizes como expediente para desqualificar, pela lei sucessorial em vigor no Império Romano do Oriente, eventuais pretendentes à coroa ${ }^{(1)}$. Tendo-se demonstrado fisicamente apto a zelar pelos seus interesses de soberano - tão fisicamente apto, aliás, que logo julgariam necessário decapitá-lo - Justiniano II deu com seu exemplo, inconscientemente, uma grande lição de Ciência Política a seu povo; a partir de sua morte viria a ser outro o gênero de mutilação utilizado para afastar do poder indivíduos tidos por indesejáveis. $O$ sucessor do "rhinotmetus", o imperador Bardanes, já se tornaria, em 713, inabilitado para governar, graças ao emprego da nova técnica da perfuração dos olhos - idêntico destino viriam a ter, posteriormente, Constantino VI, Miguel V O Calafate, o proto-sebasta Aleixo Comneno, Isaac II e João IV Lascaris ${ }^{(2)}$.

A opção dos bizantino pelo cegamento como método de resolução de seus problemas sucessórios, embora comporte algo de chocante, nem por isso deixa de exprimir uma estimativa bastante correta das reais condiçōes do poder. Com efeito, é evidente que existem estreitos vínculos entre o controlar e o ver, entre o ser controlado e o ser visto - quando a visibilidade se faz sinônimo perfeito do acesso à informação, o invisível é sempre o ingovernável. Não por acaso Foucault ${ }^{(3)}$ pôde definir o Panóptico de Bentham como a expressão máxima da

(1) Cf. WALTER, Gérard - "A vida quotidiana em Bizâncio" Lisboa, Livros do Brasil, s.d., p. 248. Antes de 705, além de Justiniano II, já haviam sofrido tal mutilação o mesmo Leôncio (698 d.C.) que lhe usurpara o trono e dois irmãos de Constantino IV (681 d.C.) (Cf. WALTER, G. - Op. cit., p. 248).

(2) Cf. WALTER, G. - Op. cit., p. 248-62. Proto-sebasta era o título honorífico reservado aos parentes mais próximos do Imperador; João IV reinava somente no Império de Nicéia, estado que durante o século XIII representou, para os bizantinos, a base da reconquista de sua capital, submetida desde a IV Cruzada a uma nobreza católica de procedência estrangeira.

(3) Cf. BOBBIO, Norberto - "O futuro da democracia", Rio de Janeiro, Paz e Terra, 1986, p. 97-8. 
dominação: nessa estrutura arquitetônica que ressalta e traduz a assimetria das relações de poder, o único e exclusivo detentor deste último será forçosamente aquele que tudo vir do alto da torre central, sem jamais ser visto pelos que ficarem embaixo, no anel periférico das celas ${ }^{(4)}$. Não por acaso, tampouco, o próprio Bentham se viu obrigado a concluir que a utilização sistemática de seu invento por uma sociedade democrática apenas seria cabível à medida que todos os vigias do Panóptico pudessem ser, eles mesmos, permanentemente vigiados em suas torres pelo público - a soberania popular, afinal, só poderia então subsistir através da completa conversão do poder concentrado pelos vigias em um poder na prática observável por todo e qualquer cidadāo ${ }^{(5)}$.

Ainda que a visibilidade do poder não pareça à primeira vista, constituir ur. tema jurídico, na acepção mais restrita deste termo, "enfocar aqui especificamente" tal assunto pode nos ser de grande proveito, pois isso permite realçar um aspecto fundamental da problemática do direito de ser informado no mundo contemporâneo. Realmente, apenas a partir de tal enfoque é que é possível uma avaliação aproximada do potencial democratizador que este direito carrega consigo, enquanto instituto jurídico destinado não só a obrigar o Estado a se expor à vigilância pública, mas também a sujeitar os meios de comunicação social a uma atuação condizente com a necessidade que as democracias têm, de que os governados sempre encontrem franqueado o acesso às informaçōes indispensáveis para que se possam governar.

A questão do papel do direito de ser informado dentro do sistema democrático, como será mostrado mais adiante, pode ser concebida como uma atualização de um dos temas mais tradicionais da Filosofia Política, qual seja, o da dependência da forma de governo em relação à extensão territorial dos estados. Já Aristóteles ${ }^{(6)}$ sustentava a tese de que o governo popular somente seria viável em uma pólis cujo tamanho não constituísse óbice nem ao comparecimento freqüente dos cidadãos aos locais comuns de deliberação, nem ao conhecimento, por todos, do caráter de cada um. A própria obsessão que o pensador grego nutria pela determinação dos limites espaciais da capacidade auditiva das mul-

(4) O Panopticon, concebido inicialmente por Bentham como um meio arquitetônico para aperfeiçoar o sistema penitenciário, consistiria basicamente em um conjunto de celas separadas, onde ficariam os detentos, dispostas em círculo. No centro de tal círculo deveria haver uma torre do alto da qual os presos pudessem ser a qualquer momento observados, sem que jamais soubessem se estavam ou não então sendo vigiados.

Necessário lembrar, aliás, que o utilitarista britânico logo vislumbraria a possibilidade de dar novas funções a seu invento, estendendo-o a inúmeras outras áreas da vida social, entre as quais o ensino e a indústria. (Cf. Bobbio, N. - Op. cit., p. 97-9).

(5) Cf. BOBBIO, N. - Op. cit., p. 18-9.

(6) Cf. EDEL, Abraham - "Aristotle". New York, Dell, 1967, p. 152; cf. KITTO, H.D.F. - "Os gregos”. Coimbra, Arménio Amado, 1970, p. 109. 
tidōes traduzia, aliás, uma acentuada preocupação de conciliar as dimensōes da área e da população da cidade-estado, com um regime do qual o efetivo acesso dos governados às informaçōes concernentes aos negócios públicos representava um ingrediente básico ${ }^{(7)}$.

A compreensão, por Aristóteles, da incompatibilidade existente entre a vastidão territorial e o governo popular decorreu, em última análise, do fato do filósofo estar plenamente cônscio de que um governo do público só poderia ocorrer em público. Com efeito, tanto Aristóteles quanto seus contemporâneos podiam perfeitamente perceber o nexo de interdependência que havia entre tal regime e o ideal da visibilidade, sendo digno de registro que, na época, os próprios críticos da democracia tenham precisado recorrer, para denegri-la, à comparação das assembléias a espetáculos públicos ${ }^{(8)}$. Muito significativamente, Platão ${ }^{(9)}$ veio a vincular, nas "Leis", os conceitos de democracia e "teatrocracia", ao definir esta última como "a democracia em matéria de música", em meio a suas costumeiras denúncias da incapacidade do homem comum de julgar o que é bom ou mau, seja nas arquibancadas dos teatros ou na praça pública. A visibilidade da ágora e de toda a cidade era, pois, na Grécia antiga, unaninemente reconhecida como o sustentáculo do governo da cidade pela ágora, descontentando os partidários da aristocracia não menos do que o fazia a própria forma democrática de governo ${ }^{(10)}$.

Não seria exagero, certamente, citar-se a fragmentação política da Grécia como um dos fatores determinantes do êxito da experiência democrática helênica. De fato, em um país dividido por inúmeras cidades-estado, muitas das quais reunindo menos de 5000 cidadãos $^{(11)}$, a exigüidade territorial destas permitia a

(7) Lembra, aliás, Claude Mossé, que a Assembléia dos cidadãos (a "Ekklésia") tinha o direito de tomar conhecimento de todas as questões de interesse para a vida da pólis, inclusive das referentes à segurança do Estado (Cf. MOSSÉ, Claude - "Atenas: a história de uma democracia" Brasília, UNB, 1982, p. 109). Sobre a obsessão de Aristóteles mencionada, ver EDEL, A. - Op. cit., p. 152.

(8) Cf. BOBBIO, N. - Op. cit., p. 85.

(9) Apud BOBBIO, N. - Op. cit., p. 85. Como bem nota Bobbio, a oposição do filósofo grego à "teatrocracia", isto e, à prescrição, pelo público de leigos, dos rumos da arte musical, nada mais constitui do que uma expressão a mais da crença de um aristocrata na inconveniência de se deixar ao homem comum - visto como inepto, despreparado e incapaz - a condução da sociedade.

(10) A apologia platônica do segredo de Estado e do recurso do governante à mentira deve ser entendida, não restam dúvidas, dentro deste contexto.

(11) Cf. KITTO, H. - Op. cit., p. 109. Necessário lembrar, aqui, que, para os gregos, a pólis era mais uma sociedade política autônoma do que, propriamente, um ente político independente dotado de território. Os cidadâos, por isso mesmo, viviam reunidos em sua pólis, ao invés de "habitarem" nela. 
constituição de espaços homogêneos passíveis de ser dominados por todos os olhares, acabando por favorecer, dessa forma, naturalmente, o surgimento de um espaço público dentro do perímetro de diversas "poleis"(12). Desconsideradas três exceçōes ${ }^{(13)}$, nenhuma das cidades-estado tinha, realmente, mais de 20 mil cidadãos, e áreas diminutas como a da ilha de Ceos comportavam não raro vários governos, exércitos e sistemas monetários distintos ${ }^{(14)}$ - a visibilidade do poder despontava, assim, dentro desse quadro, como uma verdadeira imposição do próprio fracionamento político grego. Em síntese, o fechamento da pólis no limite de seus muros contribuía de modo decisivo para que ocorresse a abertura de um espaço interno plenamente exposto, inteiramente desnudado, que o olhar dos governados podia em princípio percorrer em todos os pontos $^{(15)}$ - o mesmo espaço visível que viria a representar um componente essencial da democracia helênica.

A visibilidade proporcionada pela proximidade com o poder tende a concorrer - a confiarmos nos trabalhos dos modernos estudiosos da comunicação de massa ${ }^{(16)}$ - para que as pessoas se tornem mais inclinadas e mais aptas a julgá-lo de modo racional. Do hábito do juízo crítico à reivindicação de participar politicamente, é um só passo - talvez por isso, aliás, Habermas ${ }^{(17)}$ tenha podido verificar a existência, ao longo da história, de uma correlação quase perfeita entre a distribuição social do direito de voto e o grau de monopolização, por parte de uma ou mais classes, das condições para o acompanhamento efetivo da condução governamental dos assuntos públicos. Democracia e visibilidade plena constituem, pois, fenômenos indissociáveis, fato que não iria escapar à atenção de Montesquieu e de Rousseau quando, no século XVIII, tais autores viessem a revolucionar a Teoria das Formas de Governo herdada de Aristóteles.

(12) Cf. FORTES, L.R.S. - "Rousseau: o mundo político como vontade e representação". "Filosofia Política". Porto Alegre, LPM, 1985, v. 2, p. 107.

(13) Siracusa e Acragas (Agrigento), na Sicília, e Atenas (Cf. KITTO, H. - Op. cit., p. 110).

.(14) Cf. KITTO, H. - Op. cit., p. 110-1.

(15) Cf. FORTES, L.R.S. - Op. cit., p. 107.

(16) No que tange especificamente às alterações qualitativas que tal visibilidade propicia no comportamento político de certas populaçōes, ver LANE, Robert, e SEARS, David O. - "A opiniāo pública". Rio de Janeiro, Zahar, 1966, p. 15-9.

(17) Cf. HABERMAS, Jürgen - "Mudança estrutural da esfera pública" Rio de Janeiro, Tempo Brasileiro, 1980, p. 105-6. O sociólogo alemão, nessa parte de sua obra, demonstra a existência de um certo equilíbrio entre o acesso à riqueza, o acesso ao conhecimento e à informação e o direito de voto, nos primeiros estados liberais do continente europeu. 
Fazendo uso de sua extraordinária capacidade de observar a realidade política dos povos e de inferir a partir dela leis gerais, Montesquieu concluiu, como Aristóteles, pela incompatibilidade do regime democrático com os estados de grandes dimensões, sugerindo ser "da natureza de uma república que seu território seja pequeno"(18), bem como implicar "um grande império (...) uma autoridade despótica naquele que governa"(19). No Capítulo XX do Livro Oitavo de "Do Espírito das Leis", o filósofo francês chegou mesmo a sugerir que, sendo a forma de governo uma decorrência da extensão do Estado, dever-se-ia considerar esta última como diretamente proporcional ao grau de concentração do poder dentro do sistema político, de tal sorte que a simples redução ou ampliação dos limites de um país já poderia por si só determinar uma mudança da forma de governo ${ }^{(20)}$.

"Se tivera de escolher o lugar de meu nascimento, teria escolhido uma sociedade de tamanho limitado pela extensão das faculdades humanas (...); um Estado no qual todos os particulares se conhecessem entre si, onde as manobras obscuras do vício e a modéstia da virtude não se pudessem furtar aos olhos e ao julgamento do público (...)"(21) - este trecho do "Discurso sobre a origem e os fundamentos da desigualdade entre os homens" constitui apenas um indício a mais de que a preocupaçāo de Rousseau com o problema dos limites espaciais do "olhar público" não ficava aquém da demonstrada por Montesquieu. Havendo consagrado um capítulo inteiro de suas "Consideraçōes sobre o Governo da Polônia" a tal questão, o teórico genebrino identificou na vastidão dos grandes estados o "vício radical" destes, a "primeira e principal fonte das infelicidades do gênero humano"(22); para ele, formular aos poloneses a bizarra su-

(18) MONTESQUIEU, Charles-Louis de Secondat, Barão de - "Do espírito das leis" São Paulo, Abril Cultural, 1973, Livro VIII, Cap. 16, p. 128. Convém lembrar que, para Montesquieu, o conceito de democracia está contido na noção de "governo republicano", o qual "é aquele em que o povo como um todo, ou somente uma parcela do povo, possui o poder soberano". (Cf. MONTESQUIEU, C. - L. de S. - Op. cit., Livro II, Cap. I, p. 39).

(19) MONTESQUIEU, C. - L. de S. - Op. cit., Livro VIII, Cap. 19, p. 130. Nesse mesmo capítulo, Montesquieu associa o governo despótico aos estados de grande dimensão, afirmando que nestes só um regime de terror asseguraria a estabilidade política, já que as grandes distâncias tornariam difícil tanto o controle, pelo governante, da atuação das autoridades locais, quanto a aplicação rápida de decisōes a elas dirigidas.

(20) MONTESQUIEU, C. - L. de S. - Op. cit., Livro VIII, Cap. XX, p. 130.

(21) ROUSSEAU, Jean-Jacques - "Dedicatória" do "Discurso sobre a origem e os fundamentos da desigualdade entre os homens". São Paulo, Abril Cultural, 1973, p. 223.

(22) V. ROUSSEAU, J.J. - "Considerações sobre o governo da Polônia e sua reforma projetada”. São Paulo, Brasiliense, 1982, p. 40. 
gestão de que reduzissem voluntariamente o seu território nada mais parecia ser do que lhes apontar o único caminho possível para que seu país viesse a prosperar tal qual os pequenos estados em que "todos os cidadãos se conhecem mutuamente e se vêem uns aos outros"(23).

Poucos pensadores políticos, até hoje, igualaram Jean-Jacques Rousseau em precisão e objetividade, no enfrentamento do problema das relações entre democracia e visibilidade. De fato, o pensador suíço chegou ao âmago da questão, ao apontar a visibilidade plena como o fator diferenciador básico do regime dos pequenos estados democráticos, em relação às autocracias típicas dos grandes estados. No "Contrato Social", a democracia é apresentada como um regime próprio de estados diminutos, em cujos territórios reduzidos quase nada parece escapar à observação dos cidadãos ${ }^{(24)}$. Nas "Considerações ...", por sua vez, o distanciamento, verificado nos grandes estados, dos governados e do real mundo do exercício do poder é descrito como a causa primeira da supressão da liberdade pública - a Rousseau só podia mesmo parecer "espantoso, prodigioso, que a vasta extensão da Polônia não" houvesse "já cem vezes operado a conversão do governo em despotismo",(25).

As idéias de Montesquieu e Rousseau sobre o assunto em tela vieram a influenciar profundamente o pensamento político ocidental no tumultuado período de construção das primeiras democracias modernas, época na qual diversos teóricos procuravam, com grande esforço, conciliar as consideráveis dimensões dos estados nacionais com as exigências de um autêntico ou ao menos aparente governo popular. Datam deste tempo, por sinal, dois dos primeiros mecanismos legais destinados, ainda que não exclusivamente, a fomentar a observação pública do poder nos grandes estados: a proteção constitucional à liberdade de imprensa e o sistema federativo.

"Entre as pequenas nações", onde "o olho da sociedade penetra em toda parte", "a tirania (...) se mostra mais incômoda que em qualquer outra parte", sendo este o motivo pelo qual "a liberdade constitui (...) a condição natural da pequena sociedade"(26) - este raciocínio de Tocqueville poderia muito bem figurar nos escritos dos "founding fathers" americanos. Fascinados pelo ideário de Montesquieu, autores como Hamilton e Madison viram na limitação territorial do poder, através da divisão do Estado republicano em pequenas repúbli-

(23) V. ROUSSEAU, J.J. - “Considerações...”, p. 40 e 41.

(24) Cf. ROUSSEAU, J.J. - “Do contrato social”. São Paulo, Abril Cultural, 1973, Livro III, Cap. 4, p. 91.

(25) V. ROUSSEAU, J.J. - “Considerações...", p. 41.

(26) TOCQUEVILLE, Alexis de - “A democracia na América". Belo Horizonte, Itatiaia, 1977, p. 124. 
cas, o antídoto definitivo contra o despotismo ${ }^{(27)}$. A transformação de cada subdivisão administrativa do Estado Nacional em uma unidade com ampla autonomia lhes pareceu um meio adequado para transplantar, para o mundo moderno, a liberdade e a visibilidade do poder típicas da pólis grega. Segundo Hamilton ${ }^{(28)}$, o federalismo que propunha constituía "uma forma de estender a esfera do governo popular", atuando como uma ponte entre o modelo ideal da cidade helênica e a realidade concreta das colônias britânicas recém-libertadas.

A solução federalista imaginada pelos "founding fathers" pode não ter sido, a rigor, uma proposta original - o próprio Rousseau ${ }^{(29)}$, afinal, já chegara a sugeri-la aos nacionalistas da Polônia, quando enfim se rendera aos imperativos geográficos e se conformara com a inviabilidade de uma democracia direta neste país. Não obstante, cumpre salientar o papel desempenhado pela escola federalista no aclaramento da função democratizadora da visibilidade do Estado. Realmente, é inegável que os pensadores filiados a tal escola vieram a contribuir consideravelmente para o desenvolvimento da teoria democrática, ao elencarem entre as vantagens da descentralização governamental o fato dela trazer, ainda que só parcialmente, o poder para dentro do campo visual de todos os cidadãos ${ }^{(30)}$.

Se as ligações do Federalismo com o ideal da visibilidade são facilmente perceptíveis, as deste mesmo ideal com a defesa da liberdade de imprensa são mais do que óbvias. Por este motivo, devemos deixar agora de nos referir a estas últimas, indo tratar diretamente do assunto central deste artigo, qual seja, o

(27) Cf. ARENDT, Hannah - “Da revolução”. São Paulo, Ática, 1988, p. 123. Interessante recordar, aqui, por sinal, a visão positiva que Tocqueville teve da obra dos federalistas: para o intelectual francês, "A Uniāo" parecia "feliz e livre como uma pequena nação; gloriosa e forte, como uma grande". (Cf. TOCQUEVILLE, A. de Op. cit., p. 127).

(28) Apud ARENDT, H. - Op. cit., p. 237.

(29) Cf. ROUSSEAU, J.J. - “Consideraçōes...”, p. 41. O filósofo oitocentistas recomendou aos patriotas poloneses que nāo instaurassem um rígido controle do governo nacional sobre as províncias (palatinados), mas sim dessem a eles um alto grau de autonomia, a fim de impedir a implantação de governos centrais despóticos: "Formai em cada qual (dos palatinados) tantas outras administraçōes particulares. Aperfeiçoai a forma das dietinas, estendei sua autoridade sobre os respectivos Palatinados; mas marcai cuidadosamente os limites e fazei com que nada possa romper entre elas o laço da comum legislação e da subordinação ao corpo da República. Em uma palavra, aplicai-vos a estender e aperfeiçoar o sistema dos governos federativos, o único que reúne as vantagens dos grandes e dos pequenos Estados (...)"

(30) Como bem nota Lucio Levi, um dos fundamentos do sistema federalista consiste justamente na idéia de que aproximar geograficamente o cidadāo e o poder torna este último mais visível e, portanto, mais controlável (ver LEVI, Lucio - "Federalismo" In BOBBIO, Norberto et alii - "Dicionário de política" Brasilia, UNB, 1986, p. 842). 
problema dos limites fáticos à eficácia plena do direito de ser informado enquanto instrumento assecuratório da democratização, através da atuação dos "mass media", dos vastos estados contemporâneos.

Convém advertir, todavia, desde logo, que só se analisarão aqui, dos limites fáticos supracitados, aqueles que forem de todo estranhos às situações próprias de cada estado em particular, podendo afetar de maneira idêntica ou semelhante diferentes sociedades e regimes políticos.

\section{Obstáculos à eficácia plena do direito de ser informado (1): a Opinião Pú- blica e suas limitações.}

Salvaguarda jurídica do interesse dos que se encontram sob o poder, de que se lhes participe fielmente como tal poder está sendo utilizado, o direito de ser informado constitui elemento integrante de toda ordem jurídica verdadeiramente democrática, apareça ele sob este homen juris ou sob outra designação. A consciência da imprescindibilidade de tal direito para o funcionamento de um autêntico governo dos governados não deve, entretanto, impedir que se constate que a eficácia deste instituto é em certo grau contida em virtude do próprio fato dele concernir às condições de formação da opinião pública, e não, exatamente, às da vontade popular.

Expressão espontânea e não inteiramente refletida do querer de uma comunidade ${ }^{(31)}$, a opinião pública já foi considerada, por alguns politólogos, o fundamento último do poder. Hannah Arendt ${ }^{(32)}$, por exemplo, buscou demonstrar o acerto de tal concepção, alegando que "o monarca mais poderoso e o tirano menos escrupuloso se tornam impotentes se ninguém os obedece, ou seja, se ninguém lhes dá apoio através da obediência, pois, em política, obediência e apoio acabam por ser a mesma coisa". A impropriedade, in casu, da utilização do argumento apresentado salta, porém, à vista, devido às absurdas confusões que acarreta, de forma implícita, entre o conceito de consenso e o de opiniāo pública $^{(33)}$, e entre este último e a idéia de atitude coletiva. Com efeito,

(31) Cf. FORTES, L.R.S. - Op. cit., 101. Estas características já eram apontadas na concepção rousseauniana de opinião pública.

(32) ARENDT, H. - Op. cit., p. 182. Sustentando a mesma tese, LANE, R. e SEARS, D. - Op. cit., p. 9-10.

(33) O consenso E, simultaneamente, unidirecional, porque consiste num acordo que faz as vontades convergirem no mesmo sentido, geral, porque abrange praticamente todos os membros de uma dada sociedade política, e duradouro, porque é destinado a dar a esta certa estabilidade. A opinião pública, por sua vez, é instável, porque comporta freqüentes mudanças de objeto e de posição, fragmentária e bidirecional ou pluridirecional, haja vista que não se coaduna com a idéia de unanimidade, configurando-se, como mostra Alfred Sauvy, em torno de divergências, de resistências, de oposições (Cf. SAUVY, Alfred - "A opinião pública" São Paulo, Difusão Européia do Livro, 1959, p. 8). 
se, como quer Luhmann ${ }^{(33 b)}$, a legitimidade é "uma disposição* generalizada para aceitar decisões de conteúdo não definido, dentro de certos limites de tolerância", então é evidente que, a rigor, não é nas opiniōes dos governados, mas sim nas atitudes destes, que se esteia a condição do governante. (Grifos nossos)

Assim como não há relação direta entre legitimidade e opinião pública, assim também não há identidade entre opinião pública e vontade popular, por mais que estas possam se influenciar reciprocamente. Além da óbvia diferença existente entre opinião e vontade, que dispensa maiores comentários, contribuem também para inviabilizar a ocorrência dessa sinonímia as próprias feições dadas à vontade popular pela Teoria Democrática. De fato, o embasamento da democracia no princípio do "one man, one vote" e na regra da maioria implica, na verdade, o pressuposto de que a sociedade política, como um todo, só expressa seus desejos de forma autêntica através do posicionamento uniforme do maior número dos indivíduos que a componham - a aferição da vontade popular nas democracias tem, por conseguinte, de levar em conta critérios de deverser ("devem-se considerar os indivíduos como igualmente influentes"; "devese considerar como vontade popular a da maioria") que são plenamente dispensáveis nos processos aferidores da opinião pública, os quais não requerem nada mais do que verificação empírica ${ }^{(34)}$.

Forma de governo na qual a soberania é vista como atributo dos governados, os quais devem tomar coletivamente, em condições de igualdade entre si e segundo o princípio majoritário, as decisões determinantes das posturas e das ações do Estado, a democracia destina-se, enquanto sistema dinâmico de procedimentos concatenados conducentes a tais decisōes, a consagrar, no plano político, aquela liberdade positiva que Isaiah Berlin ${ }^{(35)}$ associou tão corretamente à

(33b) LUHMANN, Niklas - "Legitimação pelo procedimento", Brasília, UnB, 1980, p. 30.

(*) Grifo nosso.

(34) É importante notar que a opinião pública se pode fracionar infinitamente, não sendo necessário lhe aplicar - como o é no caso da aferição da vontade popular - aquilo que Guizot chamou de "l'absurdité de la conséquence": a simulação da adesão, à maioria, dos na verdade não-aderentes, levada a cabo para vinculá-los ética e juridicamente aos comandos das autoridades eleitas por esta mesma maioria. (Cf. LUHMANN, Niklas - "Legitimação pelo procedimento". Brasília, UNB, 1980, p. 139).

(35) Isaiah Berlin define a liberdade negativa como "a área em que um homem pode agir sem sofrer a obstrução dos outros" - é a liberdade que Locke defenderá ao se referir à necessidade de se limitar o poder do Estado, para que este não possa mais violar os "direitos naturais" conservados mesmo na transição do "estado de natureza" para o "estado civil" É a liberdade contra o Estado - o indivíduo é livre à medida que o Estado não interfira em sua vida.

O conceito de liberdade positiva, por sua vez, prende-se à idéia de autonomia, ou se- 
idéia kantiana de autonomia. O regime democrático representa, desse modo, a superação do dilema "liberdade individual ou Estado?" que dominou, por exemplo, o pensamento de Hobbes e Locke, tendo o primeiro defendido a supressão desta liberdade, e o segundo, a diminuição do Estado ${ }^{\left({ }^{(3)}\right.}$ - síntese da autonomia e do Estado, a democracia é a liberdade do indivíduo no Estado ${ }^{(37)}$, tornada viável graças a uma convivência coletiva inspirada na concepção da sociedade como uma reunião voluntária de indivíduos igualados pela Natureza ou nivelados na própria feitura do contrato social ${ }^{(38)}$.

Se, pois, é correta a colocaçāo feita por Bobbio ${ }^{(39)}$, de que “jamais será suficientemente advertido, contra toda tentação organicista recorrente (...), que a doutrina democrática repousa sobre uma concepção individualista da sociedade", óbvio é, então, que carece de sentido a identificação da opinião pública com a vontade popular, se entendida esta última de acordo com os parâmetros de tal doutrina ${ }^{(40)}$. Inconfundível que é quer com a maioria, quer com o total,

ja, à idéia de que a vida e as decisōes do indivíduo sejam na verdade determinadas por ele próprio, e não por forças externas. Numa acepção kantiana, a autonomia seria "a qualidade que a vontade tem de ser lei para si mesma", consistindo, assim, em um poder do indivíduo de reger-se a si mesmo. (V. BERLIN, Isaiah - "Quatro ensaios sobre a liberdade". Brasília, UNB, 1981, p. 135-6; V. BOBBIO, N. - "Direito e Estado no pensamento de Emanuel Kant”. Brasília, UNB, 1984, p. 62).

(36) Cf. BOBBIO, N. - “Direito e Estado...”, p. 37.

(37) Permitindo que as leis emanem de uma vontade pública que, como ressalta Rousseau, "é tanto minha quanto de qualquer outro", a democracia torna os indivíduos livres só por pertencerem ao povo; dentro desse quadro, as leis do Estado democrático não vêm em prejuízo da liberdade individual, porque constituem expressão dela, uma vez que através do Estado cada indivíduo (como membro de uma totalidade) institui normas para si próprio (considerado singularmente). (Cf. ROUSSEAU, J.J. - "Do contrato social", nota à p. 61).

(38) Lembra, a propósito, Hannah Arendt, que a idéia grega de igualdade individual, ao contrário da moderna, relevava não o fato dos homens serem nascidos iguais, mas sim o nivelamento convencional produzido através da instituição artificial da "pólis". (Cf. ARENDT, H. - Op. cit., p. 24-5).

(39) BOBBIO, N. - "O futuro da democracia", p. 13. Observam, aliás, Habermas e Bachrach, que muitos dos teóricos modernos aberta ou veladamente contrários à doutrina democrática não raro expressam seu desapreço por esta investindo contra a concepção individualista de sociedade que a embasa (Cf. HABERMAS, J. - "A crise de legitimação no capitalismo tardio". Rio de Janeiro, Tempo Brasileiro, 1980, p. 156-7; cf. BACHRACH, Peter - "Crítica de la teoría elitista de la democracia". Buenos Aires, Amorrortu, 1973, p. 63).

(40) Para a defesa da tese contrária à da identidade entre vontade popular e opinião pública, confiram-se as idéias de Carl Schmitt a respeito do tema, em FARIA, José Eduardo - "Retórica política e ideologia democrática". Rio de Janeiro, Graal, 1984, p. 106. 
das opiniões individuais somadas como unidades equivalentes, a opinião pública não se molda em conformidade com uma regra análoga à do "one man, one vote"(41); muito pelo contrário, ela resulta de processos complexos nos quais, na prática, não atua o princípio democrático da igualdade individual de influência. Enquanto o governo popular sempre foi relacionado, pelo pensamento político, ao tema da igualdade individual ${ }^{(42)}$, o que caracteriza a formação da opinião pública parece ser, no fundo, uma manifesta desigualdade entre os indivíduos, no que tange às oportunidades para exercer influência ${ }^{(43)}$.

Considerada a encarnação da racionalidade e como tal cultuada no período histórico em que se afirmaram as teses do Liberalismo, a opinião pública tem perdido, desde o século XIX, a indevida fama de juiz infalível, sensato e independente por definição. Ainda, porém, que tenham ocorrido alguns excessos nesse movimento revisionista - a maioria dos quais, aliás, decorrentes da tentativa de certas doutrinas políticas elitistas de apresentar a opinião pública como un mutável coro de homens-massa intrinsecamente incapazes - há de se admitir a necessidade de descartar desde logo como ingênua a concepção desta como um ente autônomo exclusivamente dedicado à tarefa de emitir juízos racionais e adequados à realidade. Com efeito, assim como os estudos mais recentes têm justificado a falência do mito da opinião pública "omnicompetente", indicando que as preferências desta se criam com base mais em "slogans" e imagens simples do que em uma percepção acurada das alternativas representadas pelos partidos e facções nas disputas políticas relevantes ${ }^{(44)}$, assim também têm tais estudos conduzido à conclusão de que o "government by public opinion" almejado pelos oitocentistas, implicando uma verdadeira contradictio in terminis, acabaria por acarretar, na prática, um "government through public opinion" no fundo gerenciado pelo que o direito austríaco denomina "empresas de tendência", ou seja, a submissão da sociedade política a um modo manipulatório de governar de todo incongruente com o princípio democrático da auto-

(41) Cf. SAUVY, A. - Op. cit., p. 9, 16 e 19.

(42) .Ver, entre outros, ARISTÓTELES - “A Política" São Paulo, Atena Editora, 1963, Livro VI, Cap. IV. $\S 2 \%$, p. 233; ARENDT, H. - Op. cit., p. 24-5; ROUSSEAU, J.J. - "Do contrato social", Livro III, Capítulo IV, p. 91; TOCQUEVILLE, A. de - Op. cit., p. 49 e 340-1; JOUVENEL, Bertrand de - "As origens do Estado moderno" Rio de Janeiro, Zahar, 1978, p. 165; BACHRACH, P. - Op. cit., p. 132 e 140; LUHMANN, N. - Op. cit., p. 142; e HABERMAS, J. - “A crise...”, p. 155.

(43) Cf. SAUVY, A. - Op. cit., p. 16.

(44) Cf., por exemplo, LANE, R. e SEARS, D. - Op. cit., p. 106; e SEARS, David "Political Behaviour" In: LINDZEY, G. e ARONSON, E. (eds.) - "The Handbook of Social Psychology" 2a ed., Reading (Ma.), 1968-9, V. 5, p. 324. 
nomia do povo ${ }^{(45)}$. Como notam Umberto Eco ${ }^{(46)}$ e Georges Burdeau ${ }^{(47)}$, a opinião pública é hoje em grande parte regida de maneira heterônoma, sendo vista quase que como simples matéria-prima oferecida à propaganda; heterodirigida, ela mais e mais se configura como a projeção dos desejos introjetados pelo público sujeitado às campanhas de persuasão efetuadas via "mass media"(48). Dentro desse quadro, não é de se estranhar que o mero assegurar da publicidade dos atos governamentais pelo direito não mais baste para garantir que o fornecimento de informações fiéis aos governados seja por si só idôneo para permitir que estes formulem de modo independente as suas opiniões sobre os assuntos de Estado.

“Eu não tenho dúvidas, desde o final da Guerra, de que uma coisa o leitor alemão não queria de forma alguma, a saber, refletir. Nessa direção orientei os meus jornais" - essa confissão de Axel Springer ${ }^{(49)}$, cujas empresas constituem o cerne do oligopólio da difusão de notícias na Alemanha Ocidental, ilustra bem o total abandono, verificado em nossa época, do ideal da publicidade crítica pelo qual a burguesia se batera em seu confronto com o Absolutismo. Cada vez mais, impōe-se hoje, com a ajuda de uma secreta política de interesses, uma publicidade meramente demonstrativa e manipulativa, cuja função precípua consiste em fazer ressuscitar um modelo político de representaçăo neofeudal, no qual a Autoridade se confirme não através de um apoio meditado dos governados, mas sim por meio de uma adesão irrefletida por parte destes, propiciada graças à permanente apresentação do Estado como espetáculo ${ }^{(50)}$. Anulando os efeitos libertários do acesso popular às informaçōes, paradoxalmente, no mes-

(45) Cf. MARCONDES Fo, Ciro (org.) - "Imprensa e capitalismo", Sāo Paulo, Kairós, 1984 , p. 82 e 162; cf. MILLS, C. Wright - "A elite do poder", 3르 ed., Rio de Janeiro, Zahar, 1975, p. 362. No direito austríaco, chamam-se "empresas de tendência" às empresas detentoras dos "mass media", as quais geralmente obtêm a maior parte de suas receitas da venda de sua influência sobre o público para os anunciantes.

(46) ECO, Umberto - “Apocalípticos e integrados”. São Paulo, Perspectiva, 1987.

(47) Apud VENÂNCIO Fo. A. - "Democracia e informação". "Revista Brasileira de Estudos Políticos", nos 60/61, Belo Horizonte, U.F.M.G., 1985, p. 449. No mesmo sentido, HABERMAS, J. - “Mudança estrutural...”, p. 235.

(48) ECO, U. - Op. cit., p. 261. No mesmo sentido, HABERMAS, J. - “Mudança estrutural...", p. 202; WEISS, Walter - "Effects of the Mass Media of Communication" In: LINDZEY, G. e ARONSON, E. (eds.) - Op. cit., v. 5, p. 176; e MILLS, C.W. Op. cit., p. $367-8$ e 378.

(49) Apud MARCONDES Fº, C. - Op. cit., p. 121.

(50) Cf. KEY Jr., V.O. - "Public Opinion and American Democracy". New York, Alfred Knopf, 1961, p. 393-4; cf. HABERMAS, J. - "Mudança estrutural...", p. 2102, 235-7, 245 e 270; cf. BOBBIO, N. - "O futuro da democracia”, p. 95; e ALMINO, João - "O segredo e a informação". S. Paulo, Brasiliense, 1986, p. 40-1. 
mo momento em que o permite, a publicidade manipulativa nada mais busca do que explorar o potencial aclamativo de diversos segmentos do público; apelando para os anseios e temores coletivos em sua dimensão mais irracional, ela contribui decisivamente para a consolidação do moderno caráter plebiscitário da esfera pública, convertendo, assim, a política em simples objeto de consu$\mathrm{mo}^{(51)}$.

Falar, como fazem alguns autores ${ }^{(52)}$, em um "Estado-espetáculo", torna-se hoje mais oportuno do que nunca. Há pouco, mesmo, se pôde presenciar a transformação do Império Britânico em uma formidável transmissão de tevê, em um "Royal Wedding" que fora integralmente imaginado e preparado para esse veículo, a tal ponto que os próprios cavalos que conduziam as carruagens dos noivos haviam sido previamente tratados com pílulas especiais, para que seu esterco assumisse uma tonalidade pastel, entre o bege e o amarelo, não vindo, desse modo, a chamar a atenção dos telespectadores ${ }^{(53)}$. Na era da televisão, a política toma, inclusive, as feições de uma novela, passando os políticos, à maneira dos atores profissionais, a ser julgados individualmente pelo público de acordo com sua imagem pessoal, seu desempenho no vídeo e seu papel no enredo apresentado ao longo dos telejornais, programas de entrevistas e debates ${ }^{(54)}$. Requisitando, como mostrou McLuhan ${ }^{(55)}$, um envolvimento em profundidade da parte do seu público, tal meio de comunicação tende a favorecer, aliás, naturalmente, a tendência da política moderna de adquirir, aos olhos dos governados, o caráter de uma sucessão veloz de rituais comoventes entremeada por disputas entre grandes personalidades.

Cada vez mais submetida a uma publicidade aclamativa que, longe de assegurar o direito de ser informado, corrompe-lhe o sentido, a opinião pública tem, a cada dia, mais reduzida a sua independência enquanto pólo decisório,

(51) Cf. ECO, U. - Op. cit., p. 262; cf. HABERMAS, J. - “Mudança estrutural...”: p. 209-10 e 212; cf. ALMINO, J. - Op. cit., p. 40-1.

(52) Especialmente R.G. Schwarzenberg, criador de tal expressão, e Norberto Bobbio (cf. BOBBIO, N. - "O futuro da democracia", p. 95).

(53) Cf. ECO, U. - "Viagem na irrealidade cotidiana". Rio de Janeiro, Nova Fronteira, 1984, p. 197-9. Trata-se aqui, é claro, do casamento do Príncipe Charles com Lady Diana Spencer, cerimônia que demonstrou com clareza a identidade existente entre a antiga publicidade aclamativa, conservada pela monarquia britânica ao longo dos últimos séculos, e a publicidade desvirtuada do Estado contemporâneo.

(54) Cf. WEISS, W. - Op. cit., p. 174.

(55) McLUHAN, H. Marshall - "Os meios de comunicação como extensões do homem". São Paulo, Cultrix, s.d., p. 356 e 375-9. Sobre o problema da personalização da política, ver também MILLS, C.W. - "A nova classe média" Rio de Janeiro, Zahar, 1976, p. 352-3. 
afastando-se, desse modo, do ideal democrático da autonomia dos governados. Afogados pelos "mass media" em um mar de símbolos de condensação( ${ }^{(56)}$, os seus respectivos mas não raro coincidentes públicos sofrem crescente influência por parte de uma imprensa-instituição que, afirmando-se acima de qualquer conflito de interesses, na verdade atua como um narrador que os induz a assumir a posição de um auditório apático ${ }^{(57)}$; erroneamente convencida de que determina o enredo narrado, a opinião pública vê-se, assim, progressivamente sujeitada a um processo de manipulação que a maioria dos legisladores parece ter evitado ou não ter ainda conseguido impedir. Embora o direito de ser informado desponte, em nosso tempo, como um remédio ao qual as democracias podem e devem recorrer para dificultar a manipulação de informaçōes, tornando os controladores da mídia passíveis de responsabilização por toda e qualquer distorção ou sonegação destas, forçoso é admitir que o pensamento jurídico ainda está longe de elaborar mecanismos legais eficazes no refreamento daquilo que Stopinno ${ }^{(58)}$ tão bem denominou "manipulação psicológica" - isto é, a ativação ou desativação dos dinamismos psicológicos inconscientes dos membros do público provocadas oculta e intencionalmente por certos grupos de interesse, com vistas a compelir esse mesmo público a adotar condutas e opiniōes que ilusoriamente aparentem derivar de sua própria livre opção.

\section{Obstáculos à eficácia plena do direito de ser informado (2): a enganosa transparência do Estado contemporâneo.}

A democracia requer o exercício, pelos governados, de uma fiscalização contínua e eficaz sobre os governantes, a qual, evidentemente, apenas pode ocorrer em estando o Estado franqueado à vista do público. Da Antiguidade até o século XVIII, tal franqueamento foi, porém, lucidamente reputado impossível nos grandes estados, cujas dimensões inviabilizavam, entāo, de plano, qualquer tentativa de se tornar o poder transparente para a maioria do povo. Cônscios de que o grau de controle dos governados sobre o Estado correspondia, grosso modo, à extensão da área perscrutável pelos sentidos destes, os autores do período - como mostramos anteriormente - entendiam que o regime democrático

(56) Os símbolos podem ser referenciais ou de condensação. Os primeiros constituem "meios econômicos de referência a elementos objetivos em objetos ou situaçōes"; os segundos prestam-se à evocação de emoções associadas consciente ou inconscientemente a determinadas situaçōes.

Segundo Murray Edelman, a utilização sistemática, por parte dos "mass media", de símbolos de condensação acarreta a emocionalização da política e o triunfo da publicidade manipulativa. (Cf. EDELMAN, Murray - "The symbolic uses of politics". Chicago, University of Illinois Press, 1977, p. 6, 8-9 e 11).

(57) Cf. KEY Jr., V.O. - Op. cit., p. 391 e 393-4.

(58) STOPPINO, Mario - "Manipulação". In: BOBBIO, N. et alii- Op. cit., p. 728-9. 
só poderia sobreviver, na prática, em territórios diminutos. Entre tais autores figurava, aliás, Montesquieu ${ }^{(59)}$, o qual diria, em "Do Espírito das Leis":

"Sendo a propriedade natural dos pequenos estados serem governados como república, a dos estados de tamanho medíocre serem submetidos a um monarca, a dos grandes impérios serem dominados por um déspota, segue-se que, para manter os princípios do governo estabelecido, é necessário manter o Estado na grandeza que já tinha; e que esse Estado muda de espírito à medida que seus limites forem reduzidos ou ampliados".

O ponto central da problemática dos limites da eficácia do direito de ser informado consiste, justamente, na determinação exata do alcance deste instituto enquanto mecanismo destinado a assegurar a visibilidade do poder, numa época em que o extraordinário estágio de desenvolvimento das técnicas de transmissão e divulgação de informações parece haver encurtado todas as distâncias, redefinindo os significados de "localidade" e de "proximidade"(60) e mudando, assim, "o espírito" dos estados de tamanho considerável. Com efeito, prolongamentos que são dos próprios sentidos humanos, os "mass media" expandem os campos visual e auditivo dos governados, e aparentam, por isso mesmo, ser capazes de gerar - se para tanto compelidos por um Legislador hábil - as condições materiais necessárias para o surgimento, nos vastos estados nacionais de nosso tempo, de uma transparência democratizadora análoga à da pólis grega. Daí porque consciente disso, um moderno comentarista de Aristóteles - Abraham Edel ${ }^{(61)}$ - chegará até a insinuar que a tese aristotélica da incompatibilidade entre os grandes territórios e o governo popular estaria, no mundo da comunicação de massa, simplesmente superada, enquanto Lewis Mumford ${ }^{(62)}$ e Cornelius Castoriadis ${ }^{(63)}$ não hesitarão em ressaltar que o rádio e a televisão teriam tornado possível, hoje em dia, uma visibilidade estatal comparável ou superior à existente na Ática do século V a.C.

Embora haja um fundo de razẩo nessas interpretaçōes quase delirantes da realidade de nossa época, faz-se preciso levar em conta, desde logo, duas im-

(59) MONTESQUIEU, C.L. de S. - Op. cit., Livro VIII, Cap. XX, p. 130.

(60) Cf. WEISS, W. - Op. cit., p. 79; cf. LANE, R. e SEARS, D. - Op. cit., p. 15-9.

(61) EDEL, A. - Op. cit., p. 152.

(62) Apud CASTORIADIS, Cornelius - "Socialismo ou barbárie". São Paulo, Brasiliense, 1983, p. 145.

(63) Cf. CASTORIADIS, C. - Op. cit., p. 145-6. 
portantes advertências, se não se deseja crer ingenuamente que a mera consagração do direito de ser informado fará os "mass média" transformarem de imediato os estados nacionais modernos em versōes ampliadas da ágora helênica. Em primeiro lugar, é necessário reconhecer que os meios de comunicação social, ao mesmo tempo em que aproximam os homens pelo som e a imagem, estabelecem, por força de sua própria intermediação, novas distâncias entre eles $^{(64)}$. Em segundo lugar, cumpre sempre frisar que a simples abertura do complexo Estado contemporâneo aos olhos do público não é por si só suficiente para assegurar que este mesmo público, carente dos conhecimentos especializados indispensáveis para a compreensão de decisões políticas de fachada técnica, venha a controlar totalmente o exercício do poder pelas autoridades e seus subordinados ${ }^{(65)}$. Ninguém, de fato, foi mais simplório do que certo ex-candidato à prefeitura de São Paulo que, pretendendo ampliar tanto a transparência desta quanto a participação popular nos procedimentos decisórios municipais, propôs a discussão pública do orçamento municipal em grandes estádios de futebol, como se tal processo pudesse efetivamente garantir o controle, por parte da população, das complicadas finanças da Administração local ${ }^{(66)}$.

A aparente superação, ao menos no que toca à questão da visibilidade do poder, do problema clássico das relações entre o tamanho do Estado e o regime nele vigorante ${ }^{(67)}$ não deve, na era dos "mass media", criar a ilusão de que, forçados estes pela Lei a divulgar informações fiéis sobre assuntos públicos, já ficaria de pronto assegurada ao direito de ser informado uma eficácia absoluta. Realmente, por maior que seja a transparência estatal, sempre haverá áreas da gestão da coisa pública que, mesmo desocultadas, não poderão na prática ser fiscalizadas pelos governados, aos quais falta o sofisticado instrumental analíti-

(64) Cf. ALMINO, J. - Óp. cit., p. 88. O tema será objeto de análise na parte final deste artigo.

(65) Cf. HABERMAS, J. - "Mudança estrutural...” p. 212; cf. B ALLE, Francis. - "Institutions et publics des moyens d'information". Paris, Éditions Montchrestien, 1973, p. 204; cf. LAFER, Celso - "A reconstrução dos direitos humanos". São Paulo, Cia. das Letras, 1988, p. 257.

(66) Quase igualando nosso candidato em ingenuidade, Castoriadis chega a sugerir que, dentro de um breve período, o desenvolvimento dos "mass media" pderá ensejar a conversão da França em uma pólis eletrônica, passando todas as decisões publicamente relevantes a ser tomadas em gigantescas assembleias gerais envolvendo toda a população do país. (Cf. CASTORIADIS, C. - Op. cit., p. 145-6).

(67) A rigor, como nota Raymond Aron, o clássico problema dos condicionamentos políticos decorrentes da "dimensão estatal" permanece ainda hoje em aberto, embora sob novas roupagens. $\mathrm{Na}$ era dos "mass media", a questão central deste deixa, aliás, de ser a da invisibilidade dos distantes centros do poder, passando a ser a das influências exercidas sobre o subsistema político pelo próprio "volume da sociedade" (conceito durkheimiano que moderniza o de "grandeza do Estado" usado por Montesquieu). Cf. ARON, Raymond - "As etapas do pensamento sociológico". São Paulo, Martins Fontes, 1987, p. 28). 
co necessário para compreender o que nelas ocorre ${ }^{(68)}$. Domínio exclusivo dos tecnocratas, depositários de conhecimentos técnicos não-acessíveis ao homem comum $^{(69)}$, tais áreas, ao que tudo indica, podem manter-se indefinidamente indevassáveis para a maioria dos cidadãos, a despeito de quaisquer eventuais tentativas que se façam de divulgar maciçamente os fatos a elas relativos.

Se nem a radical democracia ateniense do século IV a.C. logrou impedir a formação, em seu seio, de quistos tecnocráticos embrionários ${ }^{(70)}$, esperar que os estados contemporâneos pudessem escapar incólumes ao fenômeno tecnocrático seria certamente absurdo. Com efeito, intervencionista como é por definição, o chamado Estado pós-keynesiano vê-se compelido a delegar crescentes poderes aos especialistas que pōe a seu serviço, até porque, se não o fizer, corre o risco de ter bastante comprometida a sua eficiência enquanto centro regulador do sistema econômico e coordenador do processo de "engenharia social". Precisando gerar de forma incessante torrentes de decisões técnicas relacionadas às mais díspares matérias, ele tende a fortalecer naturalmente os detentores da competência indispensável para o êxito da atuação estatal, tornando-os cada vez menos dependentes dos representantes eleitos pelo povo ${ }^{(71)}$. Disso resulta, aliás, o fato de que em toda parte parece hoje se estar verificando o surgimento de uma espécie de mandarinato aristocrático, cuja influência na gestão dos negócios públicos tem sido legitimada ora com base na estranha alegação de que o poder do especialista seria apolítico ${ }^{(72)}$, ora através da combinação do argumento da competência com a velha tese elitista da incapacidade do homem comum $^{(73)}$.

(68) Cf. LAFER, C. - Op. cit., p. 257-8; cf. BOBBIO, N. - "O futuro da democracia", p. 101; cf. HABERMAS, J. - "Mudança estrutural...", p. 271.

(69) Cf. LAFER, C. - Op. cit., p. 257; cf. BOBBIO, N. - "O futuro da democracia", p. 101 .

(70) Cf. MOSSÉ, C. - Op. cit., p. 110-1.

(71) Cf. MILIBAND, Ralph - “O Estado na sociedade capitalista”. Rio de Janeiro, Zahar, 1982, p. 68; cf. LAFER, C. - Op. cit., p. 257-8; cf. JOUVENEL, B. de - Op. cit., p. 335; e cf. FARIA, J.E.C. de O. - Op. cit., p. 162.

(72) Cf. MILIBAND, R. - Op. cit., p. 68 e cf. FARIA, J.E.C. de O. - Op. cit., p. 168. Sobre os dimensionamentos intencionalmente ou não incorretos do que seja "o político", e sobre os seus efeitos em um regime formalmente democrático, V BACHRA$\mathrm{CH}, \mathrm{P}-\mathrm{Op}$. cit., p. 118 e șegs.

(73) Em "Komplexität und Demokratie", Niklas Luhmann aparenta - dentro da linguagem eufemística e evasiva que usualmente emprega em suas críticas ao ideal moderno da democracia participativa - recorrer à combinação mencionada, como que para sustentar a conveniência do Estado contemporâneo se organizar de acordo com o princípio enunciado por Grotius, de que "é justo que quem não se pode reger seja regido por outro" (Cf. HABERMAS, J. - "A crise...", p. 166; V. GROCIO, Hugo - 
Assim como o critério "aristocrático" da competência técnica se choca com o critério democrático da decisão popular, assim também à visibilidade democrática se contrapõem o segredo e a pseudovisibilidade tecnocráticos. A aparição e expansão dos bolsões tecnocráticos dentro da estrutura estatal ocasiona, por isso mesmo, uma progressiva ocultação do poder, a qual se traduz até mesmo em uma redefinição do segredo, que perde a sua tradicional conotação negativa para se tornar um recurso válidg para se conseguir maior eficácia na aplicação das "policies" governamentais ${ }^{(74)}$. Se, todavia, por um lado o segredo pode ser suprimido ou ao menos confinado em áreas restritas da gestão do Estado, através de um simples aumento do grau de exposição deste à observação pública, por outro lado é evidente que tal aumento não basta, por si só, para transformar em transparência real a pseudovisibilidade do que Bobbio chamou de "subgoverno" dos especialistas. De fato, o exercício do poder só será totalmente fiscalizável, na era das tecnocracias, a partir do instante em que se iniciar um processo permanente de tradução das informacões técnicas oriundas do Estado para termos inteligíveis ao homem comum ${ }^{(76)}$ - o direito de ser informado, nos fins do século XX, não pode deixar de implicar também um direito à explicação, sob pena de perder sua própria razão de ser.

\section{Obstáculos à eficácia plena do direito de ser informado (3): a mídia e as distorções no processo informativo.}

A discussão sobre o direito dos governados de terem acesso às informações publicamente relevantes sempre se pautou, do século XVIII em diante, pelo princípio de que todos os desvirtuamentos da função informativa da imprensa-instituição decorriam, em última análise, do modo pelo qual era determinado o conteúdo das mensagens emitidas pelos "mass media",(77). A desco-

“Del derecho de la guerra y de la paz". Madrid, Editorial Reus, 1925, t. II, Livro II, Cap. V, II, 1, p. 27).

Para uma crítica do argumento da competência, V. CASTORIADIS, C. - Op. cit., p. 143 e 217 e segs. Para uma defesa da validade de tal argumento, in casu, V BOBBIO, N. - "O futuro da democracia", p. 101.

(74) Ninguém, decerto, julgaria de modo favorável um governo que viesse a informar previamente alguns empresários, ou a divulgar pela imprensa, que estava estudando a possibilidade de aplicar medidas de eficácia dependente do efeito-surpresa. Congelamentos de preços e outras medidas de impacto tamberm hoje consideradas como inseríveis na esfera de competência do poder público parecem tornar o segredo algo mais do que um simples expediente para afastar os governados do poder.

(75) V. BOBBIO, N. - "O futuro da democracia”, p. 103.

(76) Cf. BALLE, F. - Op. cit., p. 204; cf. HABERMAS, J. - "Mudança estrutural", p. 271. No mesmo sentido, mas enfocando a questão específica do acesso a bancos de dados, V. COMISSÃO INTERNACIONAL DE JURISTAS - "O Universo Computacionário" “O Correio da Unesco". Rio de Janeiro, FGV, n 9, p. 18.

(77) A melhor crítica a esta ingênua concepção continua a ser a de McLUHAN, H.M. Op. cit., p. 25-6. 
berta, pela moderna Teoria da Comunicação, de que estes últimos têm efeitos próprios, derivados de suas características intrínsecas e absolutamente independentes daquilo que venha a ser na prática veiculado, conduziu, porém, nas últimas décadas, tanto à falência do mito da impotência da mídia como força política, o qual antes havia legitimado a ausência de um controle do público sobre as empresas dedicadas à atividade informativa, quanto à constatação de que tal controle, por mais rigoroso que fosse, jamais lograria impedir que os meios de comunicação social viessem a atuar de maneira bastante dúbia enquanto instrumentos de democratização do sistema político ${ }^{(78)}$. Esta dubiedade, por sinal, veio não apenas a gerar grande desconcerto no campo da ciência supracitada, ensejando a aparição simultânea de estimativas comicamente otimistas e histericamente catastrofistas do impacto das novas técnicas de difusão sobre a sociedade ${ }^{(79)}$, como também a colocar em xeque a ingênua tese de que os "mass media", só de serem forçados a respeitar um direito dos receptores à informação veraz, já viabilizariam prontamente a implantação, nos vastos estados contemporâneos, de um governo popular nos moldes helênicos.

Se a simples existência dos meios de comunicação social não representa, por si só, nem mesmo em sociedades que reconheçam o direito de ser informa-

(78) Sobre a existência de um poder da mídia em si, independente do conteúdo das mensagens por esta veiculadas, V. McLUHAN, H.M. - Op. cit., p. 21-38, 231, 334-9 e, sobretudo, 342-4; V. ECO, U. - "Viagem...", p. 166 e 295; V. WEISS, W. - Op. cit., p. 174; e V. PIGNATARI, Décio - "Informação, linguagem, comunicação". 16a ed., São Paulo, Cultrix, s.d., p. 13.

Sobre o mito da impotência da mídia, nascido com os trabalhos do sociólogo americano P. Lazarsfeld e de outros pioneiros no estudo do impacto político dos "mass media" sobre a sociedade, V. McQUAIL, Denis - "Mass Media" In: KUPER, A. e KUPER, J. (eds.) - "The Social Science Encyclopedia" London, 1985, p. 499 e V. McLUHAN, H.M. - Op. cit., p. 35 e 334-5.

Sobre a insuficiência do controle do conteúdo das mensagens como meio de determinar os efeitos dos "mass media", V. McLUHAN, H.M. - Op. cit., p. 343.

(79) São tais estimativas que permitem que Umberto Eco divida os atuais téricos da Comunicação em "apocalípticos" e "integrados", identificando, ainda, com a corrente mais radical destes últimos (a dos "superintegrados" ou "parusíacos"), a doutrina de H.M. McLuhan.

Segundo Eco, os apocalípticos se caracterizariam pela crença de que a racionalidade humana e o individualismo seriam inevitavelmente corroídos graças à ação persistente das modernas técnicas de difusão; os integrados, por uma avaliação ingenuamente otimista dos efeitos sociais do emprego destas mesmas técnicas; e os parusíacos, por fim, pela defesa entusiástica da tese de que o rádio e a tevê estariam aprimorando aspectos da sensibilidade e da Razão humanas há séculos menosprezados pela cultura escrita, gerando, dessa forma, um novo homem. "Se os apocalípticos são parentes tristes de Noé" - esclarece o autor italiano - "os parusíacos são primos alegres dos Reis Magos" (V. ECO, U. - "Apocalípticos e integrados", p. 9; V. ECO, U. - "Viagem...", p. 167-8 e 291 e segs.; cf. XIFRA-HERAS, Jorge - "A informação: análise de uma liberdade frustrada". São Paulo, EDUSP, 1974, p. 59-60. 
do, garantia absoluta da efetiva vigência do regime democrático, nem por isso deixam eles de contribuir enormemente para o surgimento das condiçōes objetivas para o desenvolvimento deste último. Com efeito, reduzindo distâncias e redefinindo os significados de "localidade" e "proximidade", os "mass media", especialmente o rádio e a televisão, expandem de modo considerável os campos visual e auditivo dos governados, tornando o poder muito menos distante, logo bem mais fiscalizáve ${ }^{(80)}$. Proporcionando, por outro lado, grande celeridade à circulação de notícias, as modernas técnicas de difusão constituem-

se em permanente fator de incentivo ao envolvimento público nos atos decisórios estatais, conferindo a estes maior impacto e dando ao povo ao menos a possibilidade de tomar posição a tempo de influir no desenrolar dos acontecimentos ${ }^{(81)}$. "Um servo da gleba medieval", lembra Umberto Eco ${ }^{(82)}$, "não podia fazer nada para aprovar ou desaprovar a Primeira Cruzada, da qual tomaria consciência anos depois; o cidadão da metrópole contemporânea, imediatamente em dia sobre a Crise Cubana, pode tormar partido" - talvez seja, aliás, justamente por isso, que só o segundo merece, a rigor, ser chamado de cidadão.

Onde os "mass media" chegam, as barreiras de classe e de cultura são rapidamente corroidas e as populações progressivamente incorporadas à "Aldeia Global", vindo a desmoronar a Autoridade firmada na tradição e a tornar-se cada vez mais difícil conter as maiorias antes conformadas com sua exclusão dos processos de distribuição social da riqueza e do poder ${ }^{(83)}$. Aproximado subitamente, pela comunicação de massa, do mundo outrora invisível das pessoas cujas decisões influenciam a vida coletiva, o homem comum pode, realmente, pela primeira vez, conhecê-lo e vir a ter perspectivas, remotas ou não, de dele participar. Não é por acaso, portanto, que as doutrinas elitistas recriminam sistematicamente o rádio e a tevê por haverem exposto este mundo a quem a ele nāo pertencia - "quem leva os assuntos de Israel a estranhos", afinal, sempre "profana o nome de Deus" (84). Não é por acaso, tampouco, que críticas como a

(80) Cf. WEISS, W. - Op. cit., p. 79; cf. LANE, R e SEARS, D. - Op. cit., p. 15-9; cf. POOL, Ithiel de S. - "Political Communication: Introduction". In: SILLS, David (ed.) - "International Encyclopedia of the Social Sciences". London, Macmillan, 1968 , v. 3, p. 90-6.

(81) Cf. ECO, U. - “Apocalípticos...”, p. 355; cf. McLUHAN, H.M. - Op. cit., p. 230.

(82) ECO, U. - "Apocalípticos...", p. 355.

(83) Como nota McLuhan, com o advento da comunicação de massa, os excluídos “já não podem ser mais contidos (...); eles agora estão envolvidos em nossas vidas, como nós na deles". (V. McLUHAN, H.M. - Op. cit., p. 19).

Sobre os efeitos dos "mass media" como demolidores da Autoridade tradicional e como criadores de novas demandas entre os excluídos, cf. WEISS, W. - Op. cit., p. 78-9 e cf. ECO, U. - "Viagem...", p. 172.

(84) Antigo provérbio judeu, cuja popularidade na época de Cristo é atestada por Grotius. (V. GROCIO, H. - Op. cit., Livro I, Cap. II, VIII, 4, p. 105). 
que certos estetas dirigiram ao rádio, de haver prostituído a obra de Beethoven, por transformá-la em tema popular de assobio ao invés de mantê-la acessível somente aos indivíduos aptos a realizar o ideal aristocrático (ou apenas pedante) da "entrega" total ${ }^{(85)}$, encontram hoje paralelos perfeitos no âmbito do pensamento político elitista - para nos contrapormos a este, talvez devamos, por isso mesmo, tomar a defesa dos "mass media", transplantando para a moderna Teoria Democrática a ponderação de Umberto Eco ${ }^{(86)}$, de que "o homem que assobia Beethoven porque o ouviu pelo rádio já é um homem que, embora ao simples nível da melodia, se aproxima de Beethoven".

Um dos principais efeitos democratizadores das modernas técnicas de difusão de informações consiste, sem dúvida, em tornar mais diretas as ligações entre os governados e o poder efetivo, aumentando, dessa forma, substancialmente, as possibilidades de controle deste por parte daqueles. Como observa McLuhan ${ }^{(87)}$, “à medida em que aumenta a velocidade da informação, a tendência política é a de afastar-se da representação e delegação de poderes em direção ao envolvimento imediato de toda a comunidade nos atos centrais de decisão", adquirindo, então, o Governo Representativo puro, antes necessário em razão da vagarosidade da circulação de informações, um quid de democracia direta. Evidentemente, este enfraquecimento dos intermediários existentes entre o poder e o povo tende a fortalecer este último, quanto mais porque a moderna representação política, idealizada como foi em parte para conter a influência popular ${ }^{(88)}$, tem-se comprovado tão ineficiente como veículo para o governo pelos governados que já há mesmo quem fale abertamente em uma "soberania dos representantes" ${ }^{\prime(89)}$. Confirmando, aparentemente, a sombria opinião de

(85) Cf. ECO, U. - “Apocalípticos...”, p. 41 e 45.

(86) ECO, U. - “Apocalípticos...”, p. 45.

(87) McLUHAN, H.M. - Op. cit., p. 230. A tendência identificada por McLuhan somase, aliás, ao pendor natural do "Welfare State" para o fortalecimento do Executivo, favorecendo o estabelecimento de relações diretas entre este e os governados, as quais põem em xeque o papel de intermediário tradicionalmente assumido pelo Poder Legislativo. Não deixa de ser curioso registrar que, quando o Primeiro-Ministro Mendès-France, em 1954, decidiu dirigir-se pessoalmente aos franceses por meio da radiodifusão, tenham surgido incontinente alvoroçados grupos de parlamentares, denunciando com veemência o que julgavam ser uma tentativa de alijar o Parlamento das funções de "único habilitado a entrar em contato com o povo e a informá-lo como bem entender" (V. SAUVY, A. - Op. cit., p. 129).

(88) Cf. ARENDT, H. - Op. cit., p. 181. No século XIX, aliás, John Stuart Mill já insinuava que, quanto mais intermediários houvesse entre o poder e os governados, menores seriam o interesse destes pelos assuntos públicos e a influência popular na condução dos negócios de Estado. (Cf. MILL, John Stuart - "Considerações sobre o governo representativo". Brasília, UNB, 1981, p. 101).

(89) Cf. JOUVENEL, B. de - Op. cit., p. 327; cf. MOSCA, G. - Op. cit., p. 313; cf. SCAVONE, L. et alii - "A dimensão política da comunicação de massa" Rio de Janeiro, FGV, 1975, p. 27. 
Rousseau ${ }^{(90)}$, de que "o povo inglês (...) só é livre durante a eleição dos membros do Parlamento", inúmeros estudos recentes têm, de fato, demonstrado que os chamados representantes representam, no fundo, muito pouco. Nos Estados Unidos, país-vitrine do sistema democrático representativo, verificou-se, por exemplo, na década de 60 , que dois terços do eleitorado desconheciam seus representantes na Câmara e no Senado, e que, afora certas "áreas de controvérsia crônica" (como a da legislação sobre bem-estar social), os deputados defendiam posiçōes bem pouco correlatas às de seus eleitores ${ }^{(91)}$.

Embora a atuação dos "mass media" concorra, como acabamos de ver, para que surjam condições propícias ao desenvolvimento da democracia nos estados contemporâneos, nem por isso devemos fechar os olhos aos vários efeitos deletérios da comunicação de massa no plano político. Com efeito, ao mesmo tempo em que possibilita o julgamento público do comportamento das autoridades, expondo-as à observação de todos, a mídia também compromete em grande parte a objetividade deste mesmo julgamento, seja por se prestar freqüentemente à publicidade aclamativa(92), seja por dizer insistente e subliminarmente aos receptores "queiram", e não "reflitam"(93). Preenchendo a lacuna existente entre os indivíduos, de um lado, e os acontecimentos a decisões do poder, de outro, os meios de comunicação social vêem-se, aliás, compelidos, por uma série de motivos, a reduzir o imenso volume de informaçōes que coletam a umas poucas fórmulas curtas, criando, assim, para o público, um pseudoambiente de estereótipos, uma "realidade de segunda mão" totalmente inadequada para servir de referencial ao exercício da Razão ${ }^{(94)}$.

(90) ROUSSEAU, J.J. - "Do contrato social", Livro III, Cap. XV, p. 114. Para uma análise das idéias do pensador suíço sobre a representação política, cf. FORTES, L.R.S. - Op. cit., p. 89 e 94.

(91) Cf. LANE, R. e SEARS, D. - Op. cit., p. 12-3 e 106; cf. SEARS, D. - Op. cit., p. 326 e segs.

(92) A respeito do fenômeno da publicidade manipulativa, ver as indicaçōes bibliográficas constantes da nota $\mathrm{n} \div 50$.

(93) Cf. ECO, U. - “Apocalípticos...”, p. 261. A respeito da questão do impacto dos "mass media" sobre o uso da Razão, ver, entre outros, Eco, U. - “Apocalípticos...", p. 261-2 e 360; ECO, U. - "Viagem...", p. 295-6 e 299; EDELMAN, M. - Op. cit., p. 8-11; WEISS, W. - Op. cit., p. 174; HABERMAS, J. - "Mudança estrutural...", p. 193-5, 201-2, 212, 228, 242 e 270; McLUHAN, H.M. - Op. cit., p. 30 e 275; GRABER, Doris - "Press Freedom and the General Welfare". "Political Science Quarterly". Montpelier (Vermont), v. 101, n 2, 1986, p. 262-3; MARCONDES Fo. C. - Op. cit., p. 103 e MILLS, C.W. - “A nova classe média”, p. 352-3.

(94) Cf. WEISS, W. - Op. cit., p. 89; cf. MILLS, C.W. - “A nova classe média”, p. 343 e 351-2; cf. MILLS, C.W. - "A elite do poder", p. 367-8; cf. HABERMAS, J. "Mudança estrutural...", p. 201; cf. HORN, Imme - "Wirkungen von Fernsehinhalten" In: PROKOP, Dieter (org.) - "Medienforschung", Frankfurt, Fischer Taschenbuch Verlag, 1985, v. 2, p. 63. 
A exagerada acusação, feita à tevê e ao rádio, de serem eles os responsáveis pelo atual baixo nível da discussão pública dos assuntos de Estado pode ser um lugar-comum e uma expressāo a mais desse mesmo baixo nível, mas, apesar disto, comporta um longínquo fundo de verdade. Como percebeu McLuhan(95), parecem existir indícios de que, assim como o convívio com as seqüências unifọrmes e contínuas da escrita e a transmissão de conhecimentos através delas favoreceram o desenvolvimento do raciocínio linear entre as populaçōes letradas, assim também a imagem em mosaico da televisão e a "câmara de eco" do rádio estariam afetando e transformando o modo de pensar e de ver o mundo, de seus públicos habituais - induzidos por tais "media" a abandonarem gradualmente o raciocínio linear, tais públicos estariam, assim, perdendo pouco a pouco a habilidade para inferir e criticar por meio de silogismos, e se tornando cada vez mais persuadíveis através de imagens envolventes e de "argumentos retóricos" como o aforismo(96). Além disso, a capacidade dos modernos meios de comunicação social, de dar às pessoas uma ilusória sensação de participação e um falso sentido do imediato parece estimular, como bem nota Umberto $\mathrm{Eco}^{(97)}$, a adoção coletiva de condutas irracionais. Não é de se estranhar, portanto, que às vésperas da Segunda Guerra Mundial, Orson Welles tenha podido deflagrar, narrando pelo rádio a história de uma invasão marciana, uma onda de pânico em diversas áreas dos Estados Unidos ${ }^{(98)}$; nem é de se estranhar, tampouco, que, na Itália, uma transmissāo-surpresa de tevê tenha conseguido causar grande comoção popular, veiculando a notícia inverossímil de que o filho de certa personalidade fora raptado pelo famoso ator Salerno, e

Interessante observar que o próprio fato incontestável de que os "mass media" em grande parte moldam a concepção de realidade dos seus receptores já põe por terra uma das mais populares teorias modernas sobre a influência da comunicação de massa sobre o comportamento político de seu público: a Teoria do "Two-StepFlow".

Sustentando que os "mass media" não afetariam diretamente a conduta da maioria dos receptores, mas apenas contribuiriam para a tomada de posição de "líderes de opinião", os quais poderiam então vir a influenciar os outros indivíduos, a Teoria do "Two-Step-Flow" desmoronou, nas últimas décadas, graças a inúmeros estudos empíricos que comprovaram, entre outras coisas, que mensagens veiculadas em jornais e em estações de rádio e tevê podem atingir diretamente o público e influenciá-lo de modo considerável. (Cf. RENCKSTORF, K. - "Zur Hypothese des 'two-step-flow' der Massenkommunikation”. In: PROKOP, D. (org.) - Op. cit., p. 29, 31-2, 37-42 e 47; cf. WEISS, W. - Op. cit., p. 146, 153 e 176-7).

(95) Cf. McLUHAN, H.M. - Op. cit., p. 30 e 375; cf. ECO, U. - “Viagem...”, p. 295-6.

(96) Cf. ECO, U. - “Viagem...”, p. 299. Necessário ressalvar que McLuhan não crê que o abandono do raciocínio linear e da inferência via-silogismo signifique, para o homem contemporâneo, um mergulho na irracionalidade que seria típica das culturas pré-le tradas. (Cf. McLUHAN, H.M. - Op. cit., p. 30).

(97) Cf. ECO, U. - “Apocalípticos...”, p. 343.

(98) Cf. McLUHAN, H.M. - Op. cit., p. 337; cf. ECO, U. - “Apocalípticos...”, p. 343. 
apresentando como "delegado encarregado do caso" um conhecido comediante $\mathrm{e}^{(99)}$.

A existência da televisão implica, por si só, uma série de resultados negativos para a democracia, e dentre eles, sem dúvida, o mais grave é a exacerbação do caráter teatral da atividade política. Levando às últimas conseqüências a concepção personalista desta última presente em toda a imprensa moderna, este meio de comunicação tende naturalmente a mostrar a disputa pelo poder como um embate de indivíduos proeminentes, de figuras patriarco-autoritárias das quais "se gosta ou não", ao invés de relacioná-la aos problemas estruturais da sociedade (100). Rebaixada, assim, ao nível de uma novela centrada nos conflitos de seus personagens, a política adquire as feições de um espetáculo curioso cujos atores devem ser julgados individualmente, pelo público, com base sobretudo nos critérios televisivos de avaliação: imagem pessoal, desempenho no vídeo e papel no enredo ${ }^{(101)}$. Não é por outra razão que se multiplica, hoje em dia, em todo o mundo, o número de líderes políticos com prévia experiência profissional em artes cênicas, a ponto de ex-atores de cinema virem a chefiar movimentos oposicionistas na Índia e na França e mesmo a ocupar cargos como a presidência dos Estados Unidos. Atuando claramente no sentido de estabelecer uma Autoridade fundamentada no carisma dos governantes ${ }^{(102)}$, a tevê reduz pouco a pouco a importância do processo de legitimação racional-legal necessário à manutenção de uma democracia estável, ao mesmo tempo em que, fazendo o poder passar a originar-se da notoriedade que dele constituía antes mero efeito colateral, converte-se ela própria em um meio de distribuição de influência e prestígio no interior da sociedade ${ }^{(103)}$.

Da mesma forma que algumas das características intrínsecas dos "mass media" modernos implicam a criação de vários obstáculos à democracia no mundo contemporâneo, também o próprio modo pelo qual tais "media" transmitem mensagens a seus públicos acarreta, inevitavelmente, o surgimento de situações que dificultam o funcionamento de um autêntico governo popular. Com efeito, ainda que fosse possível colocar o rádio, a tevê e os jornais totalmente a serviço da promoção da participação consciente dos cidadãos no processo político, ainda assim o direito de ser informado tão essencial ao regime

(99) Cf. ECO, U. - “Apocalípticos...”, p. 343.

(100) Cf. MARCONDES Fo, C. - Op. cit., p. 103; cf. MILLS, C.W. - "A nova classe média”, p. 352; cf. HABERMAS, J. - "Mudança estrutural...”. p. 194; cf. WEISS, W. - Op. cit., p. 174.

(101) Cf. WEISS, W. - Op. cit., p. 174.

(102) Cf. POOL, I. de S. - Op. cit., p. 94; cf. MARCONDES Fº. C. - Op. cit., p. 103.

(103) Cf. MILLS, C.W. - “A elite do poder”, p. 90; cf. KEY Jr., V.O. - Op. cit., p. 400. A respeito desse fenômeno, o episódio da candidatura presidencial de Sívio Santos parece ser bastante elucidativo. 
democrático continuaria fadado a ter a sua etıcácia contida, em virtude de diversos fenômenos que se verificam ao longo da cadeia comunicativa, restringindo ou tornando parcialmente inútil o acesso dos receptores à informação

Um de tais fenômenos consiste, não há dúvida, naquilo que a Teoria da Comunicação costuma denominar "Ruído". A informação a ser levada ao público tem sempre uma fonte e um destino distintos no tempo e no espaço, e deve, por isso mesmo, ser reduzida a sinais aptos a serem transmitidos pelo emissor e decodificados pelo receptor ${ }^{(104)}$. O processo informativo que se inicia na redação do jornal, ou na estação de tevê ou rádio, e se finda na mente do sujeito receptor, está, porém, sempre sujeito a contratempos, a interferências e distorções que podem ocorrer em qualquer uma de suas fases, comprometendo a qualidade do seu produto final ${ }^{(105)}$. Tais distorçōes, que constituem o Ruído, podem apresentar inúmeras e diferentes causas, e provocam constantemente a perda ou a limitação do acesso do público às informações politicamente relevantes.

Entre os motivos mais comuns da ocorrência do Ruído, podemos mencionar o excesso de mensagens, a alta taxa de informação destas e o não-domínio, pelo receptor, do código utilizado no processo comunicativo. Se é verdade o que afirmam estudiosos da Cibernética como Norbert Wiener (106), que "não é a quantidade de informação emitida que é importante para a ação, mas antes a quantidade de informação capaz de penetrar o suficiente num dispositivo de armazenamento e comunicação, de modo a servir como gatilho para a ação", então óbvio é que os modernos "mass media", ao bombardearem indiscriminadamente o público com uma torrente de notícias dos mais díspares níveis de relevância, acabam por saturar os sujeitos-receptores, dificultando-lhes, na prática, o acesso às informaçōes realmente úteis para o exercício da cidadania. Efeito semelhante parece ser também obtido, por sinal, quando tais "media", veiculando mensagens cujo conteúdo ultrapassa o teor máximo de novidade expectável pelos receptores, torna-as virtualmente incompreensíveis para estes últimos ${ }^{(107)}$. Nenhum dos fatores de ruído ocasiona, no entanto, maiores danos ao direito de ser informado dos cidadãos, do que a ausência, no "quadro de referência cultural geral" destes, dos conceitos necessários para proceder à de-

(104) Cf. PIGNATARI, D. - Op. cit., p. 17; cf. ECO, U. - "Viagem...", p. 168-9. Importante notar, aqui, que, no caso específico da tevê e do rádio, há uma total dissociação das figuras do destinarário e do receptor, reservando-se esta última designação ao aparelho decodificador, e não, propriamente, aos membros do público.

(105) Cf. ECO, U. - “Viagem...”, p. 168-9; cf. PINATARI, D. - 17 e segs.

(106) Apud PIGNATARI, D. - Op. cit., p. 11.

(107) Cf. ECO, U. - “Apocalípticos...”, p. 383-4. 
codificação das mensagens ${ }^{(108)}$. Precisando a informação política, para ser fiel, empregar um jargão especializado, o acesso a ela estará, de fato, total ou parcialmente obstruído, se o patrimônio léxico dos receptores não lhes possibilitar a escolha de um código adequado para traduzi-la ${ }^{(109)}$. Dentro desse quadro, não deixa de ser preocupante registrar que, logo após a Segunda Guerra, pesquisas de campo tenham demonstrado que, enquanto $94 \%$ dos habitantes de um país desenvolvido como os E.U.A. podiam definir perfeitamente o que seria um "disco voador", apenas $21 \%$ deles conseguiam conceituar algo sem dúvida muito mais importante para as suas vidas - a Declaração de Direitos ${ }^{(110)}$.

A capacidade do receptor de deturpar as informaçōes tem sido, nas últimas décadas, um dos temas mais estudados pelos especialistas em Psicologia Social, os quais têm procurado sobretudo descobrir de que forma as atitudes, condutas e opiniōes prévias do público interagem com a influência que este sofre dos "mass media". A partir do momento em que Lazarsfeld, Berelson e Gaudet demonstraram a insustentabilidade da tese do poder ilimitado da mídia $^{(111)}$, desenvolveram-se inúmeras teorias destinadas a explicar como se daria tal interação, muitas delas fundadas no pressuposto de que as pessoas sempre buscariam, consciente ou inconscientemente, tornar compatíveis suas idéias, disposições e modos de agir, rejeitando ou distorcendo as informaçōes que pudessem provocar contradiçōes entre estes ${ }^{(112)}$. A mais popular dessas teorias a da Dissonância Cognitiva, formulada por Festinger em 1957 - foi justamente a que mais enfatizou esta postura ego-defensiva do receptor, sustentando que

(108) Cf. ECO, U. - “Apocalípticos...”, p. 378-9; cf. SEARS, D. - Op. cit., p. 349; cf. LANE, R e SEARS, D. - Op. cit., p. 114-5.

Para maiores explicaçōes sobre este "quadro de referência cultural geral", V. ECO, U. - "Apocalípticos...", p. 379. Em Habermas se encontra, por sinal, uma análise bastante interessante dos vínculos entre a falta de um suporte conceitual proporcionado pela educação escolar, e a tacanha contribuição ainda hoje dada pelas maiorias ao debate político. (Cf. HABERMAS, J. - “Mudança estrutural...”, p. 198-9).

(109) Cf. ECO, U. - “Apocalípticos...”, p. 378-9; cf. LANE, R. e SEARS, D. - Op. cit., p. 114-5.

(110) Cf. LANE, R. e SEARS, D. - Op. cit., p. 105 e 114-5; cf. MILLS, C.W. - “A nova classe média", p. 356.

(111) Da Primeira Guerra Mundial até o final da Segunda, prevaleceu, na Europa e nos Estados Unidos, a tese sustentada pelos publicitários da época, de que "somente o custo limita o condicionamento da opinião pública em qualquer sentido e sobre qualquer assunto". (Cf. MILLS, C.W. - “A elite do poder”, p. 369).

(112) Cf. SEARS, D. - Op. cit., p. 337 e segs.; cf. BLEDJIAN, Frank - "Theoretische Ansätze über den Einfluss der präkommunikativen Einstellungsstruktur der Rezipienten auf Bildung und Änderung von Einstellungen". In: PROKOP, D. (org.) Op. cit., p. 75-6; cf. McGUIRE, William - "The Nature of Attitudes and Attitude Change". In: LINDZEY, G. e ARONSON, E. (eds.) - Op. cit., v. 3, p. 218 e segs.; cf. WEISS, W. Op. cit., p. 88. 
ele repeliria sistematicamente tudo que viesse de encontro a suas concepções prévias, através de três manobras destinadas especialmente a protegê-las e a preservá-las de mudanças: a fuga das fontes potenciais de informações indesejáveis (exposição seletiva), o direcionamento da atenção para as informações confirmadoras de tais concepções (atenção seletiva) e o esquecimento mais rápido das informaçōes incongruentes com estas últimas (retenção seletiva) ${ }^{(113)}$.

Freqüentemente invocada, pelos detentores dos meios de comunicação social, para legitimar a ausência de um controle do público sobre estes últimos, a Teoria da Dissonância Cognitiva está caindo em descrédito, atualmente, em virtude da comprovação empírica de sua insuficiência enquanto modelo explicativo. Com efeito, diversas pesquisas mais recentes têm conduzido à contestação da validade dos antigos estudos que concluíam haver uma preferência pessoal por informaçōes "consistentes" (i.é., conciliáveis com as idéias e disposiçōes prévias) e ocorrer uma rejeição automática, por parte dos indivíduos, das informaçōes desconfirmadoras de suas expectativas ${ }^{(14)}$. Dentro desse panorama, não há mais sentido algum, realmente, nem em se continuar atribuindo aos cidadãos-receptores, de forma implícita, toda a culpa pela sua desinformação, nem em se seguir crendo - à maneira de certos autores nacionais ultrapassados - que a mídia constitua, de fato, um inofensivo agente reforçador de opiniōes preexistentes.

O reconhecimento da existência de todos esses obstáculos à eficácia plena do direito de ser informado não implica, de modo algum, a admissão da inutilidade deste instituto, cuja imprescindibilidade para o governo popular é mais do que evidente. Na verdade, a única ameaça séria a tal direito dos cidadãos, nas democracias contemporâneas, consiste mesmo na popularização, sob novas roupagens, da já merecidamente desgastada concepção liberal da mídia como um mercado livre de informações e opiniōes, no qual supostamente os consumidores determinariam a qualidade e outras características do produto, e poderiam escolher livremente os seus próprios fornecedores. Visando a justificar o impedimento da criação de mecanismos legais destinados a tornar possível a sujeição dos "mass media" a um controle público análogo àquele ao qual outros centros de poder social estão submetidos, a velha doutrina liberal se adapta, hoje em dia, ao figurino "up-to-date" da Teoria da Comunicação, para tentar evitar que se consiga consumar a substituição do obsoleto ideal da liberdade de imprensa pelo moderno ideal da liberdade de informação.

(113) Cf. KLAPPER, Joseph - "Mass Communication: Effects". In: SILLS, D. - Op. cit., p. 83; cf. McGUIRE, W. - Op. cit., p. 218; cf. SEARS, D. - Op. cit., p. 337 e segs.; cf. WEISS, W. - Op. cit., p. 88.

Para um estudo aprofundado da teoria em tela, ver BLEDJIAN, F. - Op. cit., p. $86-90$.

(114) Cf. BLEDJIAN, F. - Op. cit., p. 92-3; cf. McGUIRE, W. - Op. cit., p. 218 e segs.; cf. MARCONDES Fo, C. - Op. cit., p. 138. 
Duas teorias, basicamente, transpõem para o campo da ciência supracitada o modo liberal de compreender as relações entre os meios de comunicação social e seus respectivos públicos: a da Exposição Seletiva e a do "Feedback". De acordo com a primeira, haveria uma acentuada tendência, por parte de todos os sujeitos-receptores, para fugir, entre outras coisas, das fontes potenciais de informaçōes desconfirmadoras de suas opiniōes e atitudes pessoais, bem como para optar voluntariamente por outras "fontes" - como certos jornais e noticiários de $\mathrm{TV}^{(115)}$ - que viessem freqüentemente ao encontro de suas idéias e disposiçōes prévias ${ }^{(116)}$. Explicando, desse modo, a escolha individual desta ou daquela "fonte", como um exercício de autonomia individual condicionado apenas pelo desejo do receptor de escapar à sensação desagradável de ser desmentido e à angústia da dúvida gerada pelas contradições, a doutrina da Exposição Seletiva apresenta a mídia, como parecem reconhecer os seus próprios adeptos $^{(117)}$, como um "imenso supermercado" de informações, onde a compra eventual de mercadoria de qualidade inferior só pode decorrer da decisão espontânea dos consumidores de não pagar o preço por um produto melhor. Criada por especialistas em questōes relativas à audiência de programas de entretenimento, tal doutrina transpõe, assim, pura e simplesmente, para a análise da influência política dos meios de comunicação, o pressuposto de que o comportamento do público se caracterize por uma fuga permanente de tudo aquilo que possa provocar dissabores e aborrecimentos, e por uma procura-incessante do que cause bem-estar e prazer ${ }^{(118)}$.

"Todos os dias, todos os meses, realiza-se nas bancas de jornal e nas portas das casas um espécie de votação democrática", na qual se determina que diários atingirão quais leitores - esse comentário do "publisher" alemão Axel Springer ${ }^{(119)}$ poderia ainda, a despeito das inúmeras pesquisas provando exatamente a tese contrária ${ }^{(120)}$, figurar como epígrafe das obras de diversos autores contemporâneos. Elisabeth Noelle-Neumann ${ }^{(121)}$, por exemplo, chega mes-

(115) Usa-se, aqui, o termo "fonte" porque, aos olhos do sujeito-destinatário, o exemplar de jornal (canal) e o aparelho de tevê (receptor) se afiguram como se fossem pontos de origem das informaçōes recebidas.

(116) Cf. KLAPPER, J.T. - Op. cit., p. 83; cf. WEISS, W. - Op. cit., p. 88 e 115; cf. McGUIRE, W. - Op. cit., p. 218; cf. SEARS, D.O. - Op. cit., p. 317.

(117) V. KLAPPER, J.T. - Op. cit., p. 83; cf. WEISS, W. - Op. cit., p. 115.

(118) Cf. McGUIRE, W. - Op. cit., p. 219.

(119) Apud MARCONDES Fo, C. - Op. cit., p. 133.

(120) Cf. BLEDJIAN, F. - Op. cit., p. 93; cf. WEISS, W. - Op. cit., p. 159; cf. MERTEN, Klaus - "Zweierlei Einfluss der Medien auf die Wahlentscheidung" In: PROKOP, D. - Op. cit., p. 129; cf. KEY Jr., V.O. - Op. cit., p. 403.

(121) Apud MERTEN, K. - Op. cit., p. 127. 
mo a interpretar a alta correlação que verificou existir entre o uso da tevê como principal fonte de informação e o voto no Partido Social-Democrata Alemão, como um indício seguro de que a preferência pelos telejornais constituiria um mero efeito das predisposições políticas do público, sendo, assim, "as pessoas que vêem muita TV muito mais de esquerda que as pessoas que assistem menos" (sic). Dando pouca atenção aos recentes estudos demonstrativos da insustentabilidade da hipótese da Exposição Seletiva, tais autores insistem em representar, como se vê, a voz do sonambulismo em nossa época, parecendo, à maneira irracional do ser humano fictício criado por suas próprias teorias, fechar os olhos sistematicamente a fatos que as põem por terra, como a paradoxal preferência popular simultânea, registrada em vários países desenvolvidos, por partidos de linha esquerdista e órgãos de imprensa conservadores ${ }^{(122)}$.

Se a Teoria da Exposição Seletiva serve para que os detentores da mídia se desculpem tímida e indiretamente pelo mau desempenho desta no exercício da função informativa, a do "Feedback" lhes fornece munição para acusar duramente o público de ser o único responsável pelo estado de desinformação existente. "O povo merece sua imprensa" é a divisa hoje constantemente invocada por estudiosos como Erich Kuby ${ }^{(123)}$, para sustentar a tese de que, não tendo "o povo (...) necessidade de ser tratado como um adulto", não cabe exigir dos meios de comunicação que informem corretamente o homem comum não é este último mesmo, afinal, que força a mídia sedenta de audiência a restringir a divulgação de fatos politicamente relevantes e a veicular preferencialmente "notícias de retorno imediato", sobre crimes, esportes, grandes acidentes, corrupção e dramas individuais comoventes ${ }^{(124)}$ ? Em pleno ocaso do século XX, a idéia de que o nível e o conteúdo da informação ministrada pelos "media" a seu público são determinados exclusivamente pelos sujeitos-receptores surge, assim, para legitimar mais uma vez o desrespeito ao direito de ser informado dos cidadãos, consagrando a aceitação implícita da crença preconceituosa de que estes, seres incapazes, seriam indignos de ter acesso às iñformações necessárias para que pudessem reger livremente o seu próprio destino.

(122) Sobre as pesquisas mencionadas, cf. BLEDJIAN, F. - Op. cit., p. 93; cf. KEY Jr., V.O. - Op. cit., p. 403; cf. MERTEN, K. - Op. cit., p. 129; cf. McGUIRE, W. Op. cit., p. 219.

Um estudo aprofundado, caso a caso, desta paradoxal preferência simultânea é encontrado em MILIBAND, R. - Op. cit., p. 287.

(123) Apud MARCONDES Fo, C. - Op. cit., p. 134.

(124) Cf. EDELMAN, M. - Op. cit., p. 9; cf. WEISS, W. - Op. cit., p. 116; cf. MARCONDES Fo, C. - Op. cit., p. 21 e 134; cf. HABERMAS, J. - Op. cit., p. 201.

São Paulo, dezembro de 1989. 